\title{
Preventative effects of Lactobacillus plantarum YS-3 on oxazolone-induced BALB/c colitis in mice
}

\author{
Xia Feng ${ }^{1} \cdot$ Jing Zhang ${ }^{2} \cdot$ Yu Qian ${ }^{1} \cdot$ Ruokun Yi $^{1} \cdot$

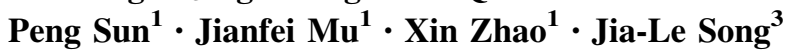

Received: 9 February 2018/ Accepted: 4 March 2018/Published online: 15 May 2018

(C) The Korean Society for Applied Biological Chemistry 2018

\begin{abstract}
In this study, the preventative effects of Lactobacillus plantarum YS-3 (LP-YS3) on colitis were studied using an in vitro animal experiment. Oxazolone was administered to $\mathrm{BALB} / \mathrm{c}$ mice to induce colitis, and the preventive effects of LP-YS3 were determined using serum- and tissue-related indexes. The mice treated with LP-YS3 showed a significant decrease $(p<0.05)$ in disease activity index for colitis by inhibiting colon shortening and increasing colon weight/length ratio. The application of LP-YS3 resulted in a significant reduction in myeloperoxidase, nitric oxide, and malondialdehyde activities and a decrease in glutathione activity $(p<0.05)$ in mouse colon tissues. LP-YS3 also significantly increased serum interleukin- 2 and reduced interleukin-10 cytokines levels in mice $(p<0.05)$. Reverse transcription-polymerase chain reaction and western blot assays showed that LP-YS3 application resulted in a significant increase in neuronal nitric oxide synthase, endothelial nitric oxide
\end{abstract}

Xia Feng and Jing Zhang have contributed equally to this work.

Xin Zhao

zhaoxin@cque.edu.cn

Jia-Le Song

songjiale@glmc.edu.cn

1 Chongqing Collaborative Innovation Center for Functional Food, Chongqing University of Education, Main Street 9, Nan'an District, Chongqing 400067, People's Republic of China

2 Department of Environmental and Quality Inspection, Chongqing Chemical Industry Vocational College, Chongqing, People's Republic of China

3 Department of Nutrition and Food Hygiene, School of Public Health, Guilin Medical University, Huancheng North 2 Road 109, Guilin 541004, Guangxi, People's Republic of China synthase, c-Kit, and stem cell factor expressions and a decrease in inducible nitric oxide synthase, interleukin-8, and $\mathrm{C}-\mathrm{X}-\mathrm{C}$ motif chemokine receptor 2 expressions in mouse colonic tissues $(p<0.05)$. These findings indicate that LP-YS3 imparts preventative effects on oxazoloneinduced colitis in mice.

Keywords Lactobacillus plantarum YS-3 - Oxazolone · Colitis · Chemokine receptor $\cdot$ Expression

\section{Introduction}

Ulcerative colitis (UC) is an inflammatory bowel disease that increases the risk of colon cancer as well as significantly alters the quality and lifestyle of people within the age range of 20-50 years [1]. Many current research studies are the pathogenesis and treatment of UC, which generally emphasize that it is essential to control the disease [2]. However, clinical treatment using UC drugs imparts side effects when administered long term. Therefore, there is a need to identify a safe and effective drug for the treatment of UC [3]. Recent investigations have shown that intestinal flora is strongly associated with UC by participating in eliciting mucosal immune responses, which is a hallmark of inflammatory bowel disease. Supplemental application of probiotics is thus considered as an effective technique in relieving symptoms of UC by regulating intestinal flora $[4,5]$.

Lactic acid bacteria are beneficial to the human body by promoting nutrient absorption, improving the function of the gastrointestinal tract, inhibiting the spread of spoilage bacteria, assisting in bolus removal, enhancing human immunity and resistance, and eliminating free radicals. 
These have also been shown to possess anti-aging and antiinflammatory properties [6, 7]. Lactobacillus can also relieve intestinal inflammation by secreting metabolites that impart stimulatory effects on intestinal mucosal lymph nodes, thereby enhancing the activity of immune systemrelated cells and macrophages [8]. Lactic acid bacteria may be directly used or acquired through the consumption of fermented food. Current research on the use of lactic acid bacteria on colitis has mainly focused on commercial strains. The present study investigated the mechanism by which lactic acid bacteria inhibit colitis progression using both in vitro and in vivo assays [9]. Some lactic acid bacteria that can prevent certain types of colitis are already used as traditional food, although details on its underlying mechanism remain unclear [10].

Yak yogurt is a common, highly nutritious, naturally fermented food used by the ethnic minority in QinghaiTibet Plateau. Studies have shown that yak yogurt has a variety of physiological activities, including anti-oxidation, inhibition of cholesterol, and improvement of immunity [11]. Qinghai-Tibet Plateau is a special natural fermentation environment, wherein yak milk is fermented in Tibetan unique fermentation vessels, which contributes to the unique yak yogurt flavor and quality [12]. We previously reported that the isolated lactic acid bacteria in Tibet has specific intestinal benefits, wherein it more effectively relieves constipation than the common $L$. bulgaricus, thereby suggesting that it may potentially be of higher commercial value. L. plantarum YS-3 (LP-YS3), which is the main component of yak yogurt made in Yushu Tibetan Autonomous Prefecture, Qinghai Province, imparts antigastric acid and anti-biliary effects. We earlier investigated the physiological activities of lactic acid bacteria in yak yogurt from Qinghai-Tibet Plateau, which exhibited antioxidative activity and preventative effects against constipation [13]. The present study assessed the effects of LP-YS3 on apoptosis in oxazolone-induced colitis in a mouse model. The results of this study provide theoretical basis for further development of LP-YS3 for public use and other therapeutic strategies.

\section{Materials and methods}

\section{Identification of microbial strain}

The isolated lactic acid bacteria were identified as $L$. plantarum YS3 (LP-YS3) from naturally fermented yak yoghurt which was obtained from a herdsman family in Qinghai-Tibet Plateau in Yushu, China, by our research team. Then, this lactic acid bacteria were submitted to the China Center for Type Culture Collection (CCTCC) under the preservation number M2016749. And the L. bulgaricus
(LB, CCTCC AB 200048) was also purchased from CCTCC, which was used in this study.

\section{Animal grouping and intervention}

Fifty BALB/c mice were randomly divided into five groups, namely normal, control, LB treatment, low-concentration LP-YS3 treatment (LP-YS3-L), and high-concentration LP-YS3 treatment (LP-YS3-H) groups, with 10 rats in each group. The normal and control groups were fed the common meal without any other treatment. The LB, LP-YS3-L, and LP-YS3-H of LP-YS3 treatment groups were intragastrically administered $2 \mathrm{~mL}$ of a suspension, respectively, containing $1 \times 10^{9}, 1 \times 10^{8}$, and $1 \times 10^{9}$ $\mathrm{CFU} / \mathrm{kg}$ [13], which was repeated for 26 days continuously. On 15th day after initiation of the experiment, a $2 \mathrm{~cm} \times 2 \mathrm{~cm}$ area on the abdomen of all mice was shaved and served as site of application of ethanol or oxazolone. Approximately $0.2 \mathrm{~mL}$ of ethanol (99\%) was applied to the abdomen of the control group, whereas $0.2 \mathrm{~mL}$ of an oxazolone solution was administered to the other groups (3\% by mass, $99 \%$ ethanol as solvent). On 19th day of the experiment, the mice were fasted for $24 \mathrm{~h}$ and later induced into anesthesia $(0.1 \mathrm{~mL} / 10 \mathrm{~g}$ in chloral hydrate). A $3.5-\mathrm{cm}$ silicon pipe was inserted into the intestines of each mouse. Approximately $0.15 \mathrm{~mL}$ of a $50 \%$ ethanol solution was injected into the control mice via the silicon pipe, whereas the other groups received $0.15 \mathrm{~mL}$ of a $1 \%$ oxazolone solution (mass ratio, $50 \%$ ethanol as solvent). The catheter was pulled out after $20 \mathrm{~s}$, and the mice were inverted for $30 \mathrm{~s}$ [5]. On the 26th day, the mice were killed, their plasma was collected, and the weight and length of the colon of each mouse were measured. In addition, disease activity index (DAI) was calculated (Table 1) using the following equation: $\mathrm{DAI}=($ Weight loss + Stool + Blood stool fraction)/3 (SYXK (Yu) 2017-0023).

\section{Determination of MPO, NO, GSH, MDA, and SOD activities of mouse colonic tissues}

The isolated colonic tissues were washed with saline solution at a volume times the weight of the colon mass.

Table 1 Disease activity index scoring standard

\begin{tabular}{llll}
\hline Weight decrease $(\%)$ & Stool character & Hematochezia & Score \\
\hline No decrease & Normal & Occult blood $(-)$ & 0 \\
$1-5$ & Normal & Occult blood (-) & 1 \\
$6-10$ & Semi-sparse stool & Occult blood (+) & 2 \\
$11-15$ & Semi-sparse stool & Occult blood (+) & 3 \\
$>15$ & Sparse stool & Visible blood & 4 \\
\hline
\end{tabular}


After washing, the colonic tissues were homogenized by ultrasonic crushing, and the MPO, NO, GSH, MDA, and SOD activities in the colon tissue were determined according to the kit instructions [14].

\section{Determination of serum inflammatory cytokine levels of mice}

The serum levels of cytokines IL-2 and IL-10 of the mice were determined using enzyme linked immunosorbent assay (ELISA) according to the instructions provided in the kit [14].

\section{Reverse transcription-polymerase chain reaction (RT-PCR) profiling of mouse colonic tissues}

RNA was extracted from homogenized tissues of the small intestine using RNAzol, and the final RNA concentration was adjusted to $1 \mu \mathrm{g} / \mu \mathrm{L}$. Approximately $1 \mu \mathrm{L}$ of oligodT18, RNase, dNTP, MLV and $10 \mu \mathrm{L}$ of a $5 \times$ buffer were added into $2 \mu \mathrm{L}$ diluted liquidity. cDNA was synthesized using the following conditions: $37^{\circ} \mathrm{C}$ for $120 \mathrm{~min}, 99{ }^{\circ} \mathrm{C}$ for $4 \mathrm{~min}$, and $4{ }^{\circ} \mathrm{C}$ for $3 \mathrm{~min}$. mRNA expression of nNOS, eNOS, iNOS, c-Kit, SCF, IL-8, and CXCR2 was determined by RT-PCR $\left(94^{\circ} \mathrm{C}\right.$ for $5 \mathrm{~min}$; followed by 30 cycles of $94^{\circ} \mathrm{C}$ for $30 \mathrm{~s}, 80{ }^{\circ} \mathrm{C}$ for $30 \mathrm{~s}$, $72{ }^{\circ} \mathrm{C}$ for $30 \mathrm{~s}$, and a final $72{ }^{\circ} \mathrm{C}$ for $5 \mathrm{~min}$ ) (Table 2). GAPDH was used an internal reference. The PCR products were resolved by $1 \%$ agarose gel electrophoresis, followed by ethidium bromide staining and analysis using Image 1.44 software [14].

\section{Western blot assay}

Approximately $0.5 \mathrm{~g}$ of colonic tissues was used in producing $1 \mathrm{~mL}$ of cell lysate from each mouse. Briefly, the tissues were homogenized and then centrifuged at $1200 \mathrm{rpm}$ at $4{ }^{\circ} \mathrm{C}$, and the supernatant was collected and stored in $-80{ }^{\circ} \mathrm{C}$ until analysis. A protein standard curve was generated to measure the protein concentration of each sample according to the instructions of the BCA protein concentration assay kit (Thermo Fisher Scientific, Waltham, MA, USA). Approximately $150 \mu \mathrm{g}$ of protein was mixed with $2 \times$ buffer solution, which was followed by $12 \%$ SDS-PAGE (Thermo Fisher Scientific) gel electrophoresis at $140 \mathrm{~V}$ for $2 \mathrm{~h}$. The resolved proteins were then transferred onto a PVDF membrane (Thermo Fisher Scientific) at $4{ }^{\circ} \mathrm{C}, 100 \mathrm{~mA}$, for $1 \mathrm{~h}$ and then blocked using $5 \%$ skim milk at $25^{\circ} \mathrm{C}$, with shaking for $1 \mathrm{~h}$. After incubating overnight at $4{ }^{\circ} \mathrm{C}$, the membranes were washed with TBST thrice, each time for $10 \mathrm{~min}$. Then, the membranes were incubated at $25^{\circ} \mathrm{C}$ for $2 \mathrm{~h}$ with a secondary antibody (Thermo Fisher Scientific), followed by washing thrice with TBST for 10 min each. Finally, the gray value of each group was compared [15].

\section{Statistical analysis}

All the experimental determinations were repeated thrice, and the average of the three experimental results was calculated. The SAS9.1 statistical software was used to analyze whether the data of each group significantly differed from each other at the $P<0.05$ level using one-way ANOVA.

\section{Results}

\section{DAI scoring of mice}

The DAI scores of mice of different groups are presented in Table 3. On the 20th, 22nd, and 25th day of the study, the mice with oxazolone-induced colitis in the control group showed the highest DAI scores, whereas the LB and LPYS3 treatment groups exhibited a reduction in DAI scores, and those that received a high concentration of LP-YS3 (LP-YS3-H group) presented the lowest DAI scores.

\section{Colon length and weight of mice}

The colon length and weight of mice are presented in Table 4. After oxazolone treatment, the colon length of the mice decreased compared to the oxazolone-untreated control mice (normal); therefore, the mice in the control group had the shortest colon, and the colon length of mice in the LP-YS3-H group was significantly higher than in the LB and LP-YS3-L groups.

\section{Measurement of enzyme activity in the mouse colon tissues}

The activity of MPO, NO, GSH, and MDA in colon tissues of mice was determined (Table 5). The MPO, NO, and MDA levels in colonic tissues of the control group were the lowest, whereas those of GSH were the highest. The MPO, NO, and MDA levels of the LP-YS3-H group were lower than those of the other groups and higher than those of the normal group. Similarly, GSH levels of the YS3-H group were almost the same as the control. The LB and LP-YS3$\mathrm{H}$ groups also had higher GSH levels and lower MPO, NO, MDA levels than the control.

\section{Serum cytokine levels of mice}

The serum IL-2 and IL-10 cytokine levels of the mice are shown in Table 6. The IL-2 levels of the control group 
Table 2 Reverse transcriptionpolymerase chain reaction primers used in this study

\begin{tabular}{|c|c|}
\hline Gene & Sequence \\
\hline \multirow[t]{2}{*}{$n N O S$} & Forward: 5'-GAA TAC CAG CCT GAT CCA TGG AA-3' \\
\hline & Reverse: $5^{\prime}$-TCC TCC AGG AGG GTG TCC ACC GCA TG-3' \\
\hline \multirow[t]{2}{*}{$e N O S$} & Forward: 5'-GGA GAG GCT GCA TGA CAT TG-3' \\
\hline & Reverse: 5'-GGT AGA GCC ATA GTG GAA TGA C-3' \\
\hline \multirow[t]{2}{*}{$i N O S$} & Forward: 5'-AGA GAG ATC GGG TTC ACA-3' \\
\hline & Reverse: 5'-CAC AGA ACT GAG GGT ACA- $3^{\prime}$ \\
\hline \multirow[t]{2}{*}{$c-K i t$} & Forward: 5'- AGA CCG AAC GCA ACT $-3^{\prime}$ \\
\hline & Reverse: 5'- GGT GCC ATC CAC TTC A - $3^{\prime}$ \\
\hline \multirow[t]{2}{*}{$S C F$} & Forward: 5'- AAA CTG GTG GCG AAT $-3^{\prime}$ \\
\hline & Reverse: $5^{\prime}$ - CAC GGG TAG CAA GAA - $3^{\prime}$ \\
\hline \multirow[t]{2}{*}{$I L-8$} & Forward: $5^{\prime}$-AGA AGC ATG GCC CAG AAA TCA-3' \\
\hline & Reverse: 5'-GGC CTT GTA GAC ACC TTG GT-3' \\
\hline \multirow[t]{2}{*}{$C X C R 2$} & Forward: 5'-GAA CAA AGG CAA GGC TAA- $3^{\prime}$ \\
\hline & Reverse: 5'-AAC ATA ACA ACA TCT GGG CA- $3^{\prime}$ \\
\hline \multirow[t]{2}{*}{ GAPDH } & Forward: 5'-CGG AGT CAA CGG ATT TGG TC-3' \\
\hline & Reverse: 5'-AGC CTT CTC CAT GGT CGT GA-3' \\
\hline
\end{tabular}

$n N O S$ neuronal nitric oxide synthase, eNOS endothelial nitric oxide synthase, $i N O S$ inducible nitric oxide synthase, $S C F$ stem cell factor, $I L-8$ interleukin-8, CXCR2 C-X-C motif chemokine receptor 2, GAPDH glyceraldehyde-3-phosphate dehydrogenase
Table 3 Disease activity indices of different groups of mice

\begin{tabular}{llll}
\hline Group & 20th day & 22nd day & 25th day \\
\hline Normal & $0.00 \pm 0.00^{\mathrm{d}}$ & $0.00 \pm 0.00^{\mathrm{d}}$ & $0.00 \pm 0.00^{\mathrm{d}}$ \\
Control & $2.12 \pm 0.26^{\mathrm{a}}$ & $2.79 \pm 0.31^{\mathrm{a}}$ & $3.22 \pm 0.28^{\mathrm{a}}$ \\
LB & $1.84 \pm 0.23^{\mathrm{b}}$ & $1.93 \pm 0.22^{\mathrm{b}}$ & $2.13 \pm 0.25^{\mathrm{b}}$ \\
LP-YS3-L & $1.71 \pm 0.20^{\mathrm{b}}$ & $1.87 \pm 0.19^{\mathrm{b}}$ & $2.01 \pm 0.23^{\mathrm{b}}$ \\
LP-YS3-H & $1.52 \pm 0.22^{\mathrm{c}}$ & $1.59 \pm 0.16^{\mathrm{c}}$ & $1.79 \pm 0.22^{\mathrm{c}}$ \\
\hline
\end{tabular}

Values presented are the mean \pm standard deviation $(N=10$ /group $)$ LB, Lactobacillus bulgaricus $\left[1 \times 10^{9}\right.$ colony-forming units $(\mathrm{CFU}) /$ $\mathrm{kg}$ body weight (bw)]; LF-YS3-L, L. plantarum YS3, low dose $\left(1 \times 10^{8} \mathrm{CFU} / \mathrm{kg}\right.$ bw $)$; LF-YS3-H, L. plantarum YS3, high dose $\left(1 \times 10^{9} \mathrm{CFUs} / \mathrm{kg}\right.$ bw $)$

${ }^{\mathrm{a}-\mathrm{d}}$ Mean values with different letters in the same column are significantly different $(P<0.05)$ based on Duncan's multiple range test

were the highest, whereas the IL-10 levels were the lowest. LP-YS3-H treatment could raise the IL-10 level and reduce the IL-2 level compared to the untreated colitis mice (control), and these levels were closest to the normal group.

\section{nNOS, eNOS, and iNOS expressions in mouse colonic tissues}

RT-PCR and western blotting observed the highest mRNA and protein expression levels of nNOS and eNOS in the colon tissues of the control mice, whereas those of iNOS were the lowest (Fig. 1, Table 7). After inducing colitis,
nNOS and eNOS expressions decreased, whereas iNOS expression increased, and LP-YS3 could inhibit these changes. The LP-YS3-H group showed higher nNOS and eNOS expression levels and lower iNOS expression levels than the LP-YS3-L, LB, and control groups.

\section{c-Kit and SCF expressions in mouse colonic tissues}

c-Kit and SCF mRNA and protein expression levels in the colonic tissues of the control group were lowest, whereas those of the normal group were the highest (Fig. 2, Table 8). c-Kit and SCF expression levels in the LP-YS3H, LP-YS3-L, and LB groups decreased, whereas those of the c-Kit and SCF in the LP-YS3-H group were only lower than those of the normal group.

\section{IL-8 and CXCR2 expressions in mouse colonic tissues}

The highest IL-8 and CXCR2 mRNA and protein expression levels were observed in the colonic tissues of the control mice (Fig. 3, Table 9). LP-YS3 and LB treatment reduced the IL-8 and CXCR2 expressions in colonic tissue, with the LP-YS3-H group exhibiting a decrease in expression levels that were closest to the normal group. 
Table 4 Colon length and ratio of colon weight/colon length of different group mice
Table 5 MPO, NO, GSH, and MDA activities in colon tissues of different mouse groups

\begin{tabular}{lll}
\hline Group & Colon length $(\mathrm{cm})$ & Colon weight/colon length $(\mathrm{mg} / \mathrm{cm})$ \\
\hline Normal & $9.6 \pm 0.5^{\mathrm{a}}$ & $40.4 \pm 2.3^{\mathrm{a}}$ \\
Control & $3.6 \pm 0.6^{\mathrm{d}}$ & $12.7 \pm 1.2^{\mathrm{e}}$ \\
LB & $5.3 \pm 0.7^{\mathrm{c}}$ & $23.1 \pm 1.5^{\mathrm{d}}$ \\
LP-YS3-L & $5.9 \pm 0.5^{\mathrm{c}}$ & $28.3 \pm 1.9^{\mathrm{c}}$ \\
LP-YS3-H & $7.7 \pm 0.5^{\mathrm{b}}$ & $35.3 \pm 1.6^{\mathrm{b}}$ \\
\hline
\end{tabular}

Values are presented as the mean \pm standard deviation $(N=10$ /group)

LB, Lactobacillus bulgaricus $\left[1 \times 10^{9}\right.$ colony-forming units $(\mathrm{CFU}) / \mathrm{kg}$ body weight (bw)]; LF-YS3-L, $L$. plantarum YS3, low dose $\left(1 \times 10^{8} \mathrm{CFU} / \mathrm{kg}\right.$ bw $)$; LF-YS3-H, L. plantarum YS3, high dose $\left(1 \times 10^{9} \mathrm{CFU} /\right.$ $\mathrm{kg}$ bw)

${ }^{\mathrm{a}-\mathrm{e}}$ Mean values with different letters in the same column are significantly different $(P<0.05)$ according to Duncan's multiple range test

\begin{tabular}{lllll}
\hline Group & $\begin{array}{l}\text { MPO } \\
(\mathrm{mU} / \mathrm{mg})\end{array}$ & $\begin{array}{l}\text { NO } \\
(\mu \mathrm{mol} / \mathrm{gprot})\end{array}$ & $\begin{array}{l}\text { GSH } \\
(\mu \mathrm{mol} / \mathrm{mg})\end{array}$ & MDA (nmol/mg) \\
\hline Normal & $6.32 \pm 0.13^{\mathrm{e}}$ & $0.31 \pm 0.06^{\mathrm{e}}$ & $8.12 \pm 0.52^{\mathrm{a}}$ & $0.42 \pm 0.04^{\mathrm{e}}$ \\
Control & $32.05 \pm 2.44^{\mathrm{a}}$ & $3.45 \pm 0.51^{\mathrm{a}}$ & $2.36 \pm 0.35^{\mathrm{e}}$ & $1.69 \pm 0.36^{\mathrm{a}}$ \\
LB & $22.31 \pm 1.71^{\mathrm{b}}$ & $2.75 \pm 0.41^{\mathrm{b}}$ & $4.02 \pm 0.45^{\mathrm{d}}$ & $1.12 \pm 0.28^{\mathrm{b}}$ \\
LP-YS3-L & $16.25 \pm 1.42^{\mathrm{c}}$ & $1.97 \pm 0.35^{\mathrm{c}}$ & $5.33 \pm 0.42^{\mathrm{c}}$ & $0.88 \pm 0.15^{\mathrm{c}}$ \\
LP-YS3-H & $9.78 \pm 0.61^{\mathrm{d}}$ & $1.06 \pm 0.40^{\mathrm{d}}$ & $6.48 \pm 0.31^{\mathrm{b}}$ & $0.63 \pm 0.14^{\mathrm{d}}$ \\
\hline
\end{tabular}

Values are presented as the mean \pm standard deviation $(\mathrm{N}=10$ /group)

MPO, myeloperoxidase; NO, nitric oxide; GSH, glutathione; MDA, malondialdehyde; LB, Lactobacillus bulgaricus $\left[1 \times 10^{9}\right.$ colony-forming units $(\mathrm{CFU}) / \mathrm{kg}$ body weight (bw)]; LF-YS3-L, L. plantarum YS3, low dose $\left(1 \times 10^{8} \mathrm{CFU} / \mathrm{kg}\right.$ bw $)$; LF-YS3-H, L. plantarum YS3, high dose $\left(1 \times 10^{9} \mathrm{CFU} / \mathrm{kg}\right.$ bw $)$

${ }^{\mathrm{a}-\mathrm{e}}$ Mean values with different letters in the same column are significantly different $(P<0.05)$ according to Duncan's multiple range test
Table 6 Serum cytokine IL-2 and IL-10 levels of different mouse groups

\begin{tabular}{lrr}
\hline Group & \multicolumn{1}{c}{ IL-2 $(\mathrm{pg} / \mathrm{mL})$} & \multicolumn{1}{c}{ IL-10 $(\mathrm{pg} / \mathrm{mL})$} \\
\hline Normal & $233.02 \pm 34.56^{\mathrm{a}}$ & $121.02 \pm 16.23^{\mathrm{e}}$ \\
Control & $66.32 \pm 15.24^{\mathrm{e}}$ & $1128.96 \pm 39.42^{\mathrm{a}}$ \\
LB & $97.52 \pm 16.12^{\mathrm{d}}$ & $765.20 \pm 31.25^{\mathrm{b}}$ \\
LP-YS3-L & $119.82 \pm 14.59^{\mathrm{c}}$ & $623.47 \pm 22.36^{\mathrm{c}}$ \\
LP-YS3-H & $184.59 \pm 21.20^{\mathrm{b}}$ & $303.25 \pm 21.02^{\mathrm{d}}$ \\
\hline
\end{tabular}

Values are presented as the mean \pm standard deviation ( $N=10$ /group)

IL-2, interleukin-2; IL-10, interleukin-10; LB, Lactobacillus bulgaricus $\left[1 \times 10^{9}\right.$ colony-forming units $(\mathrm{CFU}) / \mathrm{kg}$ body weight $\left.(\mathrm{bw})\right]$; LFYS3-L, Lactobacillus $p$. YS3, low dose $\left(1 \times 10^{8} \mathrm{CFU} / \mathrm{kg}\right.$ bw $)$; LFYS3-H, L. plantarum YS3, high dose $\left(1 \times 10^{9} \mathrm{CFU} / \mathrm{kg}\right.$ bw $)$

${ }^{\mathrm{a}-\mathrm{e}}$ Mean values with different letters in the same column are significantly different $(P<0.05)$ according to Duncan's multiple range test

\section{Discussion}

Colitis can cause weight loss, diarrhea, bleeding, and other severe symptoms, and these symptoms are used as scoring standards of DAI to determine the degree of colitis [13]. The DAI index shows that LP-YS3 decreases the symptoms of oxazolone-induced colitis, and the effects were more pronounced with a higher dose. Colon length and colonic weight/colon length ratio were used to determine the criteria for colitis, and the mouse model showed shorter colon length than the normal mouse and a lower colon/colon length ratio [16]. The results of this study show that colon length and colon weight/colon length ratio in the LPYS3 high-concentration group were significantly higher than those in the control group, which in turn were slightly lower than those in the normal group.

The observed increase in MPO activity in the colon indicates a decrease in neutrophil aggregation in inflammatory tissues [17]. During inflammation of the colon, NO generated by the iNOS aggravates colon tissue damage, which in turn increases NO content and MPO activity, thereby intensifying the degree of inflammation [3]. Colitis can also lead to excessive production of reactive oxygen 


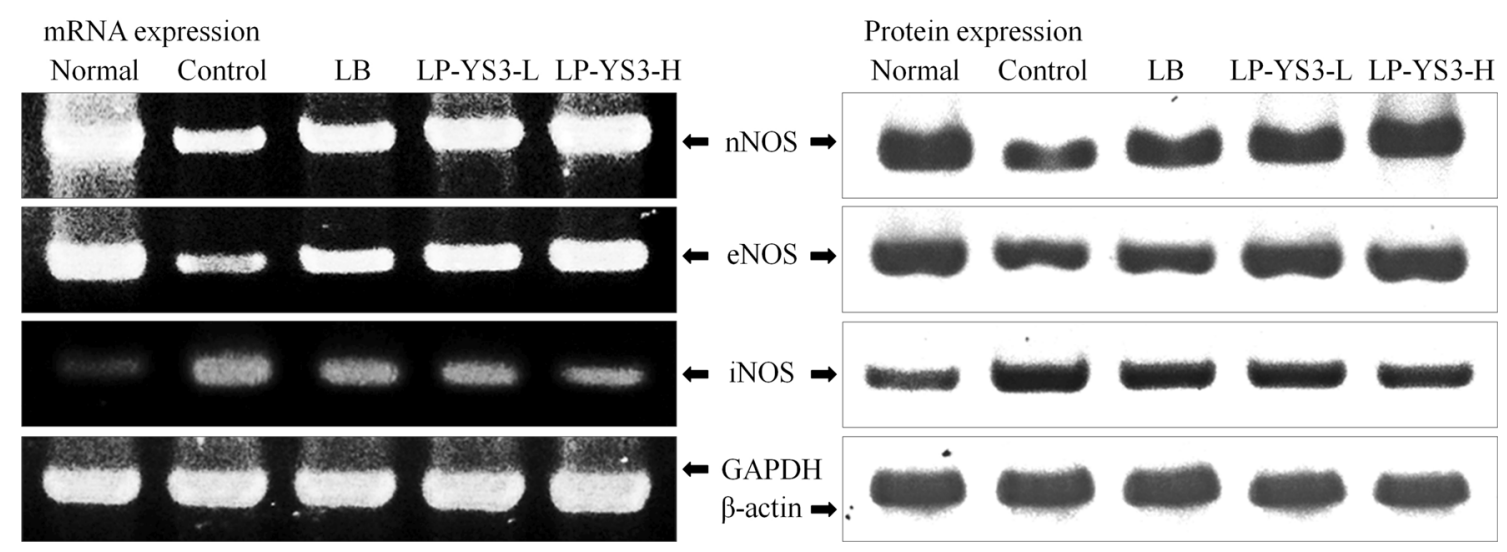

Fig. 1 nNOS, eNOS, and iNOS mRNA and protein expression levels in colonic tissues of mice treated with LB or LP-YS3. Fold ratio: gene (or protein) expression/GAPDH ( $\beta$-actin) $\times$ control numerical value (control fold ratio: 1). LB: Lactobacillus bulgaricus $\left[1 \times 10^{9}\right.$ colony- forming units (CFU)/kg body weight (bw)]; LF-YS3-L: L. plantarum YS3, low dose $\left(1 \times 10^{8} \mathrm{CFU} / \mathrm{kg}\right.$ bw $)$; LF-YS3-H: L. plantarum YS3, high dose $\left(1 \times 10^{9} \mathrm{CFU} / \mathrm{kg}\right.$ bw $)$
Table 7 Semi-quantitative analysis of nNOS, eNOS, and iNOS mRNA expressions in mouse colon tissues (fold change relative to the control group)

\begin{tabular}{|c|c|c|c|c|c|c|}
\hline \multirow[t]{2}{*}{ Group } & \multicolumn{2}{|c|}{ nNOS expression } & \multicolumn{2}{|c|}{ eNOS expression } & \multicolumn{2}{|c|}{ iNOS expression } \\
\hline & mRNA & Protein & mRNA & Protein & mRNA & Protein \\
\hline Normal & $3.74 \pm 0.35^{\mathrm{a}}$ & $1.86 \pm 0.14^{\mathrm{a}}$ & $3.63 \pm 0.21^{\mathrm{a}}$ & $1.56 \pm 0.08^{\mathrm{a}}$ & $0.18 \pm 0.04^{\mathrm{e}}$ & $0.59 \pm 0.03^{\mathrm{d}}$ \\
\hline Control & $1.00 \pm 0.06^{\mathrm{e}}$ & $1.00 \pm 0.04^{\mathrm{e}}$ & $1.00 \pm 0.06^{\mathrm{e}}$ & $1.00 \pm 0.05^{\mathrm{d}}$ & $1.00 \pm 0.09^{\mathrm{a}}$ & $1.00 \pm 0.07^{\mathrm{a}}$ \\
\hline LB & $1.47 \pm 0.12^{\mathrm{d}}$ & $1.33 \pm 0.10^{\mathrm{d}}$ & $1.63 \pm 0.05^{\mathrm{d}}$ & $1.06 \pm 0.07^{\mathrm{d}}$ & $0.78 \pm 0.06^{\mathrm{b}}$ & $0.85 \pm 0.05^{\mathrm{b}}$ \\
\hline LP-YS3-L & $1.83 \pm 0.14^{\mathrm{c}}$ & $1.64 \pm 0.11^{\mathrm{c}}$ & $1.85 \pm 0.06^{\mathrm{c}}$ & $1.29 \pm 0.12^{\mathrm{c}}$ & $0.66 \pm 0.05^{\mathrm{c}}$ & $0.80 \pm 0.06^{\mathrm{b}}$ \\
\hline LP-YS3-H & $2.01 \pm 0.16^{\mathrm{b}}$ & $1.72 \pm 0.11^{\mathrm{b}}$ & $2.02 \pm 0.11^{\mathrm{b}}$ & $1.41 \pm 0.10^{\mathrm{b}}$ & $0.52 \pm 0.05^{\mathrm{d}}$ & $0.71 \pm 0.04^{\mathrm{c}}$ \\
\hline
\end{tabular}

Values are presented as the mean \pm standard deviation $(N=10$ /group)

LB, Lactobacillus bulgaricus $\left[1 \times 10^{9}\right.$ colony-forming units (CFU)/kg body weight $\left.(\mathrm{bw})\right]$; LF-YS3-L, $L$. plantarum YS3, low dose $\left(1 \times 10^{8} \mathrm{CFU} / \mathrm{kg}\right.$ bw $)$; LF-YS3-H, L. plantarum YS3, high dose $\left(1 \times 10^{9} \mathrm{CFU} /\right.$ $\mathrm{kg}$ bw)

${ }^{\mathrm{a}-\mathrm{e}}$ Mean values with different letters in the same column are significantly different $(P<0.05)$ according to Duncan's multiple range test

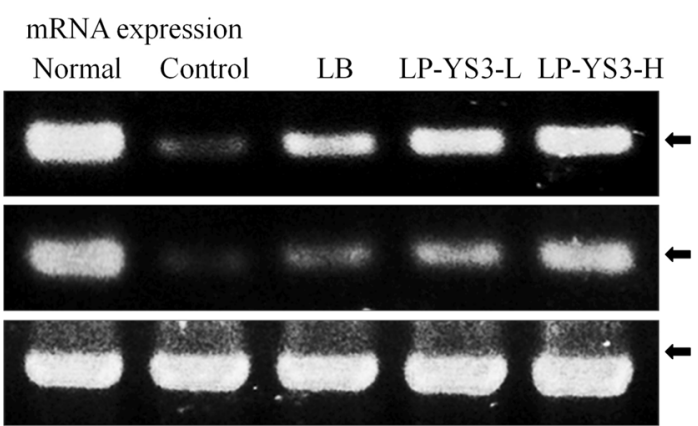

Fig. 2 c-Kit and SCF mRNA and protein expression levels in colonic tissues of mice treated with LB or LP-YS3. Fold ratio: gene (or protein) expression/GAPDH $(\beta$-actin $) \times$ control numerical value (control fold ratio: 1). LB: Lactobacillus bulgaricus $\left[1 \times 10^{9}\right.$

species (ROS) and active nitrogen species (RNS), which can lead to oxidative stress as well as damage colonic tissues [18]. Upon occurrence of an inflammatory reaction,

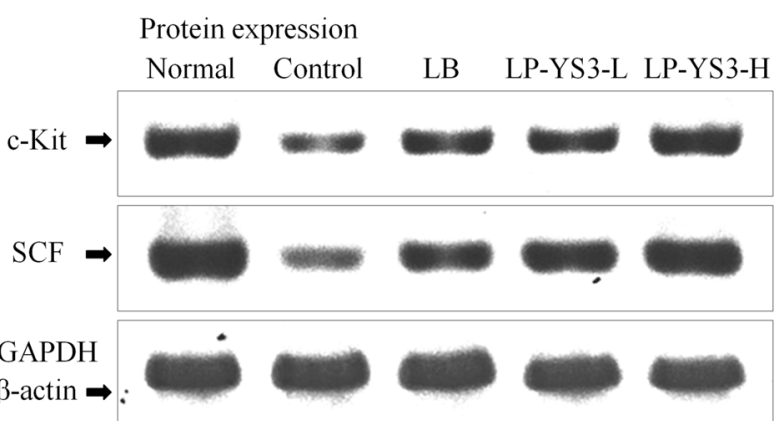

colony-forming units (CFU)/kg body weight (bw)]; LF-YS3-L: $L$. plantarum YS3, low dose $\left(1 \times 10^{8} \mathrm{CFU} / \mathrm{kg}\right.$ bw); LF-YS3-H: $L$. plantarum $\mathrm{YS} 3$, high dose $\left(1 \times 10^{9} \mathrm{CFU} / \mathrm{kg}\right.$ bw $)$

the large amount of ROS generated will destroy the body oxidation/antioxidant balance, reducing the content of GSH in colonic tissues, and extensive lipid peroxidation 
Table 8 Semi-quantitative analysis of c-Kit and SCF mRNA expressions in mouse colon tissues (fold change relative to the control group)

\begin{tabular}{|c|c|c|c|c|}
\hline \multirow[t]{2}{*}{ Group } & \multicolumn{2}{|c|}{ c-Kit expression } & \multicolumn{2}{|l|}{ SCF expression } \\
\hline & mRNA & Protein & mRNA & Protein \\
\hline Normal & $11.62 \pm 1.16^{\mathrm{a}}$ & $2.50 \pm 0.29^{\mathrm{a}}$ & $16.48 \pm 1.71^{\mathrm{a}}$ & $3.61 \pm 0.34^{\mathrm{a}}$ \\
\hline Control & $1.00 \pm 0.08^{\mathrm{e}}$ & $1.00 \pm 0.08^{\mathrm{e}}$ & $1.00 \pm 0.09^{\mathrm{e}}$ & $1.00 \pm 0.09^{\mathrm{e}}$ \\
\hline LB & $5.09 \pm 0.44^{\mathrm{d}}$ & $1.68 \pm 0.11^{\mathrm{d}}$ & $4.07 \pm 0.41^{\mathrm{d}}$ & $1.93 \pm 0.16^{\mathrm{d}}$ \\
\hline LP-YS3-L & $6.44 \pm 0.32^{\mathrm{c}}$ & $1.81 \pm 0.12^{\mathrm{c}}$ & $7.25 \pm 0.48^{\mathrm{c}}$ & $2.48 \pm 0.19^{\mathrm{c}}$ \\
\hline LP-YS3-H & $7.07 \pm 0.29^{\mathrm{b}}$ & $2.21 \pm 0.18^{\mathrm{b}}$ & $12.13 \pm 1.05^{\mathrm{b}}$ & $2.82 \pm 0.17^{\mathrm{b}}$ \\
\hline
\end{tabular}

Values are presented as the mean \pm standard deviation ( $N=10$ /group)

LB, Lactobacillus bulgaricus $\left[1 \times 10^{9}\right.$ colony-forming units $(\mathrm{CFU}) / \mathrm{kg}$ body weight (bw)]; LF-YS3-L, $L$. plantarum YS3, low dose $\left(1 \times 10^{8} \mathrm{CFU} / \mathrm{kg}\right.$ bw $)$; LF-YS3-H, L. plantarum YS3, high dose $\left(1 \times 10^{9} \mathrm{CFU} /\right.$ $\mathrm{kg}$ bw)

${ }^{\mathrm{a}-\mathrm{e}}$ Mean values with different letters in the same column are significantly different $(P<0.05)$ according to Duncan's multiple range test

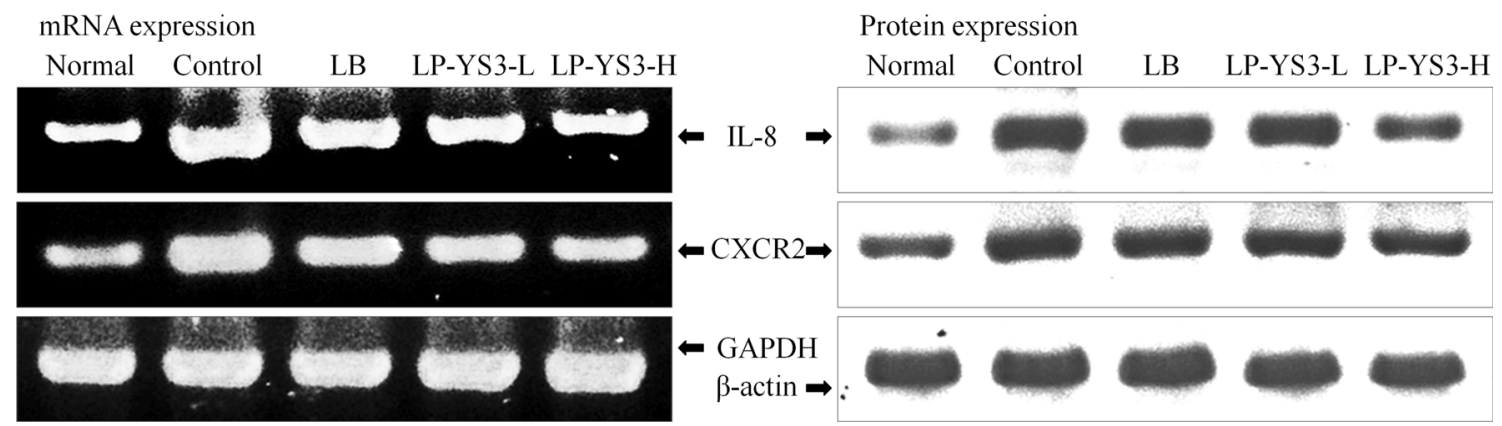

Fig. 3 IL-8 and CXCR2 mRNA and protein expression levels in colonic tissues of mice treated with LB or LP-YS3. Fold ratio: gene (or protein) expression/GAPDH $(\beta$-actin) $\times$ control numerical value (control fold ratio: 1). LB: Lactobacillus bulgaricus $\left[1 \times 10^{9}\right.$ colony- forming units (CFU)/kg body weight (bw)]; LF-YS3-L: L. plantarum YS3, low dose $\left(1 \times 10^{8} \mathrm{CFU} / \mathrm{kg}\right.$ bw $)$; LF-YS3-H: L. plantarum YS3, high dose $\left(1 \times 10^{9} \mathrm{CFU} / \mathrm{kg}\right.$ bw $)$
Table 9 Semi-quantitative analysis of IL-8 and CXCR2 mRNA expressions in mouse colon tissues (fold change relative to the control group)

\begin{tabular}{|c|c|c|c|c|}
\hline \multirow[t]{2}{*}{ Group } & \multicolumn{2}{|c|}{ IL-8 expression } & \multicolumn{2}{|c|}{ CXCR2 expression } \\
\hline & mRNA & Protein & mRNA & Protein \\
\hline Normal & $0.35 \pm 0.04^{\mathrm{e}}$ & $0.35 \pm 0.03^{\mathrm{e}}$ & $0.41 \pm 0.04^{\mathrm{e}}$ & $0.59 \pm 0.06^{\mathrm{d}}$ \\
\hline Control & $1.00 \pm 0.09^{\mathrm{a}}$ & $1.00 \pm 0.05^{\mathrm{a}}$ & $1.00 \pm 0.07^{\mathrm{a}}$ & $1.00 \pm 0.04^{\mathrm{a}}$ \\
\hline LB & $0.77 \pm 0.06^{\mathrm{b}}$ & $0.85 \pm 0.04^{\mathrm{b}}$ & $0.78 \pm 0.05^{\mathrm{b}}$ & $0.89 \pm 0.05^{\mathrm{b}}$ \\
\hline LP-YS3-L & $0.62 \pm 0.05^{\mathrm{c}}$ & $0.71 \pm 0.05^{\mathrm{c}}$ & $0.65 \pm 0.04^{\mathrm{c}}$ & $0.86 \pm 0.07^{\mathrm{b}}$ \\
\hline LP-YS3-H & $0.48 \pm 0.04^{\mathrm{d}}$ & $0.56 \pm 0.04^{\mathrm{d}}$ & $0.53 \pm 0.03^{\mathrm{d}}$ & $0.67 \pm 0.05^{\mathrm{c}}$ \\
\hline
\end{tabular}

Values are presented as the mean \pm standard deviation ( $N=10$ /group)

LB, Lactobacillus bulgaricus $\left[1 \times 10^{9}\right.$ colony-forming units (CFU)/kg body weight (bw)]; LF-YS3-L, $L$. plantarum YS3, low dose $\left(1 \times 10^{8} \mathrm{CFU} / \mathrm{kg}\right.$ bw $)$; LF-YS3-H, L. plantarum YS3, high dose $\left(1 \times 10^{9} \mathrm{CFU} /\right.$ $\mathrm{kg}$ bw)

${ }^{\mathrm{a}-\mathrm{e}}$ Mean values with different letters in the same column are significantly different $(P<0.05)$ according to Duncan's multiple range test increases MDA production [19]. Oxazolone-induced colitis is a Th2 cell-mediated inflammation. The mechanism of inflammation is that the immune network imbalance between Th2/Th1 leads to the inflammation, and cytokines IL-2 and IL-10 are produced by Th1 and Th2 cells separately, which all are directly related to colitis, and the low levels of IL-2 and high levels of IL-10 mean an increase in the degree of colitis [4]. The results also showed the similar results; LP-YS3 might inhibit the colitis based on its effects of increasing GSH, IL-2 levels and decreasing MPO, NO, MDA, IL-10 levels. 
NOS is divided into nNOS, eNOS, and iNOS. NO produced by eNOS is involved in the control of colonic tissue injury, and the excess NO produced by iNOS accelerates colonic inflammation, and nNOS downregulation also enhances iNOS expression while releasing enormous amounts of NO [20]. In addition, since the iNOS is a calcium- and calmodulin-independent enzyme that is specifically expressed during inflammation, clinical studies have shown that $100 \%$ of UC patients with inflammatory intestinal mucosal epithelial cells express iNOS, and $>50 \%$ of patients with intestinal mucosal lamina express iNOS, and no iNOS expression was seen in non-inflammatory parts [21]. After determination of qPCR and western blot, LP-YS3 could raise the nNOS and eNOS expressions and reduce iNOS expression in colitis mice; these effects were beneficial to its anticolitis effects, similar to the results of previous studies.

UC symptoms include not only diarrhea and blood in the stool, but also adverse effects on colonic motility disorders, which are related to Cajal interstitial cells (ICC) [21]. In the presence of inflammatory bowel disease, SCF has a direct effect in maintaining the number and function of ICCs. SCF is a natural ligand of c-Kit. The proliferation and differentiation of ICC after the SCF/Kit signaling pathway are reduced, thereby aggravating colitis [22, 23]. The c-Kit and SCF expressions of colitis were down-regulated by LP-YS3, these effects could inhibit colitis, the inflammatory expression regulation effects of LP-YS3 related to the mechanism of the action of LY-YS3.

IL-8 has inflammatory activity and chemotaxis, CXCR is an IL- 8 receptor, and IL- 8 and CXCR2 are associated with the pathogenesis of colon cancer. IL- 8 and CXCR2 are highly expressed in colon cancer [24], which was also observed in the present study. Chemokine is a class of small molecular basic protein, chemokines have similar structure, chemotaxis and activation, and they can mediate cell activities during inflammation and participate in tissue repair [25]. CXCR2 is a receptor of IL-8, which is mainly expressed in $\mathrm{T}$ cells, monocytes, mononuclear cells, melanoma cells, synovial fibroblasts, neutrophils, HL-60, THP-1 myeloid progenitor cells, and other cell surfaces [26]. During acute inflammatory responses, chemokines gather on the surface of endothelial cells in the presence of glucosamine and promote the release of large amounts of proinflammatory cytokines after binding to leukocytes; then, the corresponding chemokine receptor would be expressed. The CXCR2 and its ligand IL- 8 can produce chemotaxis to cause neutrophil migration, participating in the body defense response; a significant increase in neutrophils and its mediated damage causes the upregulated expression of chemokine due to an increase in the expression of their receptor, which in turn aggravates tissue damage, thereby increasing inflammatory responses [27].
Previous research showed that CXCR and IL-8 were important colitis-related gene expressions; this study also showed that LP-YS3 could reduce CXCR and IL-8 expressions and inhibit colitis through these effects.

The goal of this study was to determine the inhibitory effects of LP-YS3 on oxazolone-induced colitis in mice intestinal cells. LP-YS3 significantly reduced DAI in colitis mice, as well as inhibited the further decrease in colonic length caused by colitis, and increased the ratio of colonic weight/colon length. LP-YS3 significantly decreased the contents of MPO, NO, MDA, and IL-10 in colonic tissues of colitis rats and increased the content of GSH and the serum level of IL-2. LP-YS3 also increased the expression of nNOS, eNOS, c-Kit, and SCF and reduced the expression of iNOS, IL-8, and CXCR2 in colonic tissues, suggesting that LP-YS3 can effectively prevent oxazoloneinduced colitis and may be potentially used for probiotic development.

Acknowledgments The present research was supported by the Program for Innovation Team Building at Institutions of Higher Education in Chongqing (CXTDX201601040), Chongqing Research Program of Basic Research and Frontier Technology (cstc2016jcyjA0339) and Research Project of Chongqing University of Education (KY2015TBZC), China.

\section{References}

1. Stawowczyk E, Kawalec P (2017) Cost-effectiveness of biological treatment of ulcerative colitis-a systematic review. Prz Gastroenterol 12:90-97

2. Sun FM (2012) The pathogenesis of ulcerative colitis and therapeutic update. Guide China Med 10:445-447

3. Wei YB, Liu KR, Chen GZ (2015) Research progress of traditional Chinese in treatment of ulcerative colitis. J Liaoning Univ TCM 17:222-224

4. Cui HH, Chen CL, Sun Y, Liu YH, Wang YD, Zhang YD, Yang YJ, Pan LJ (2003) Changing of the flora and humoral immunofunction in patients with inflammatory bowel diseases. Chin $\mathrm{J}$ Microecol 15:151-155

5. Sun Y, Ding YQ (2009) Changes of intestinal flora and pathology in ulcerative colitis. Mod Digest Int 14:26-28

6. Linares DM, Gómez C, Renes E, Fresno JM, Tornadijo ME, Ross RP, Stanton C (2017) Lactic acid bacteria and bifidobacteria with potential to design natural biofunctional health-promoting dairy foods. Front Microbiol 8:846

7. Yu X, Li S, Yang D, Qiu L, Wu Y, Wang D, Shah NP, Xu F, Wei $\mathrm{H}$ (2016) A novel strain of Lactobacillus mucosae isolated from a Gaotian villager improves in vitro and in vivo antioxidant as well as biological properties in D-galactose-induced aging mice. J Dairy Sci 99:903-914

8. Del Carmen S, de Moreno de LeBlanc A, LeBlanc JG (2016) Development of a potential probiotic yoghurt using selected antiinflammatory lactic acid bacteria for prevention of colitis and carcinogenesis in mice. J Appl Microbiol 121:821-830

9. Aubry C, Michon C, Chain F, Chvatchenko Y, Goffin L, Zimmerli SC, Leguin S, Langella P, Bermudez-Humaran L, Chatel JM (2015) Protective effect of TSLP delivered at the gut mucosa 
level by recombinant lactic acid bacteria in DSS-induced colitis mouse model. Microb Cell Fact 14:176

10. Park JS, Joe I, Rhee PD, Jeong CS, Jeong G (2017) A lactic acid bacterium isolated from kimchi ameliorates intestinal inflammation in DSS-induced colitis. J Microbiol 55:304-310

11. Wu CS, Shu C, Li J, Qian Y, Suo HY (2012) The research progress and prospect of Yak yogurt lactic acid bacteria. Food Ind 2012:135-139

12. Wu CS, Li J, Qian Y, Suo HY (2012) Research progress of Yak milk and fermented Yak milk and their nutritional value. J Dairy Sci Technol 35:43-46

13. Qian Y, Suo HY, Du MY, Zhao X, Li J, Li GJ, Song JL, Liu ZH (2015) Preventive effect of Lactobacillus fermentum Lee on activated carbon-induced constipation in mice. Exp Ther Med 61:272-278

14. Zhao X, Wang Q, Li GJ, Chen F, Qian Y, Wang R (2014) In vitro antioxidant, anti-mutagenic, anti-cancer and anti-angiogenic effects of Chinese Bowl tea. J Funct Food 7:590-598

15. Zhao X, Kim SY, Park KY (2013) Bamboo salt has in vitro anticancer activity in HCT-116 cells and exerts anti-metastatic effects in vivo. J Med Food 16:9-19

16. Strober W, Fuss IJ, Blumberg RS (2002) The immunology of mucosal models of inflammation. Annu Rev Immunol 20:495-549

17. Mustafa A, El-Medany A, Hagar HH, El-Medany G (2006) Ginkgo biloba attenuates mucosal damage in a rat model of ulcerative colitis. Pharmacol Res 53:324-330

18. Osman N, Adawi D, Ahrné S, Jeppsson B, Molin G (2008) Probiotics and blueberry attenuate the severity of dextran sulfate sodium (DSS)-induced colitis. Dig Dis Sci 53:2464-2473

19. Fiocchi $C$ (2004) Inflammatory bowel disease: new insights into mechanisms of inflammation and increasingly customized approaches to diagnosis and therapy. Curr Opin Gastroenterol 20:309-310
20. Vallance BA, Dijkstra G, Qiu B, van der Waaij LA, van Goor H, Jansen PL, Mashimo H, Collins SM (2004) Relative contributions of NOS isoforms during experimental colitis: endothelial-derived NOS maintains mucosal integrity. Am J Physiol Gastrointest Liver Physiol 287:G865-G874

21. Konturek PC, Brzozowski T, Engel M, Burnat G, Gaca P, Kwiecien S, Pajdo R, Konturek SJ (2009) Ghrelin ameliorates colonic inflammation. Role of nitric oxide and sensory nerves. J Physiol Pharmacol 60:41-47

22. Li H, Lu ZH, Chen L, Lin L (2009) Expression of interstitial cells of Cajal and stem cell factors in mice colon with ulcerative colitis. Acta Univ Med Nanjing (Nat Sci) 29:648-651

23. Galli SJ, Tsai M, Wershil BK (1993) The c-kit receptor, stem cell factor, and mast cells. What each is teaching us about the others. Am J Pathol 142:965-974

24. Lee YS, Choi D, Kim NY, Yang S, Jung E, Hong M, Yang D, Lenz HJ, Hong YK (2014) CXCR2 inhibition enhances sulindacmediated suppression of colon cancer development. Int J Cancer 135:232-237

25. Binder Gallimidi A, Nussbaum G, Hermano E, Weizman B, Meirovitz A, Vlodavsky I, Götte M, Elkin M (2017) Syndecan-1 deficiency promotes tumor growth in a murine model of colitisinduced colon carcinoma. PLoS ONE 12:e0174343

26. George AL, Bednarczyk R, Rajoria S, Hanly E, Suriano R, Mittelman A, Tiwari RK (2013) Abstract 1432: cXCL8 is a secretory inflammatory stimulus of the activated TME that modulates breast cancer phenotype. Cancer Res 73:1432-1432

27. Planagumà $\mathrm{A}$, Domènech $\mathrm{T}$, Pont $\mathrm{M}$, Calama $\mathrm{E}$, García-González V, López R, Aulí M, López M, Fonquerna S, Ramos I, de Alba J, Nueda A, Prats N, Segarra V, Miralpeix M, Lehner MD (2015) Combined anti CXC receptors 1 and 2 therapy is a promising anti-inflammatory treatment for respiratory diseases by reducing neutrophil migration and activation. Pulm Pharmacol Ther 34:37-45 